Available online at: http://journal.uinsgd.ac.id/index.php/kt

Khazanah Theologia, Vol. 1 No. 1: 23-29

DOI: $10.15575 /$ kt.v1i1. 7125

\title{
Peran Perempuan dalam Tradisi Sunda Wiwitan
}

\author{
Zaenal Muttaqien \\ Pascasarjana UIN Sunan Gunung Djati Bandung \\ Email: muttaqienzet@gmail.com
}

\begin{abstract}
The Baduy community is still considered a primitive, backward, traditional and even uncivilized society. Is it true that all claims are worthy of them? According to researchers certainly not. According to the observations of researchers, the community which was considered primitive turned out to have a extraordinary civilization. One of them is related to the meaning of mutual cooperation in carrying out religious rituals in the Sundanese Wiwitan Baduy tradition. Observing religious ritual models performed by the Baduy is very interesting. Many uniqueness that we meet. The uniqueness began to be felt from the processes that were undertaken. The uniqueness is important to be published as a treasure of cultural diversity that Indonesia has. With ethnographic research found several important things: First, until now, the Baduy people still consider the tradition they carry out is a sacred obligation. Second, in the Baduy life, the existence of women and men is not to dominate each other, both of them live to complement each other. Third, the appreciation of the meaning of the ritual above, is caused by compliance with traditional rules. Baduy people understand that traditional rules (pikukuh) are a sacred heritage of Baduy's ancestors and must be obeyed at any time.
\end{abstract}

Keywords: Baduy; Gender; Local Wisdom.

\begin{abstract}
Abstrak
Masyarakat suku Baduy sampai saat ini masih dianggap sebagai sebuah masyarakat yang primitif, tertinggal, tradisional, bahkan tidak beradab. Betulkah klaim semua itu layak disandang oleh mereka?. Menurut peneliti tentu tidak. Menurut pengamatan peneliti, masyarakat yang dianggap primitif tersebut ternyata memiliki keadaban yang sangat luar biasa. Salah satu diantaranya adalah terkait dengan makna saling bekerjasama dalam menjalani ritual keagamaan dalam tradisi Sunda Wiwitan Baduy. Mengamati model-model ritual keagamaan yang dilakukan suku Baduy sangatlah menarik. Banyak keunikan yang kita temui. Keunikan itu mulai terasa dari proses-proses yang dijalani. Keunikan itu penting untuk dipublikasikan sebagai khazanah keragaman budaya yang dimiliki Indonesia. Dengan penelitian etnografis ditemukan beberapa hal penting: Pertama, sampai saat ini, Orang Baduy masih menganggap tradisi yang mereka laksanakan adalah kewajiban yang bernilai sakral. Kedua, dalam kehidupan Orang Baduy, eksistensi perempuan dan laki-laki bukan untuk saling mendominasi, keduanya hidup untuk saling melengkapi. Ketiga, penghayatan makna ritual di atas, disebabkan oleh kepatuhannya dalam memegang peraturan adat. Masyarakat Baduy memahami bahwa aturan adat (pikukuh) merupakan warisan leluhur Baduy yang sakral dan harus dipatuhi sampai kapanpun.
\end{abstract}

Kata Kunci: Baduy; Gender; Kearifan Lokal.

\section{PENDAHULUAN}

Tidak dapat disangsikan bahwa Indonesia adalah salah satu negara dengan variasi etnis dan bahasa yang kaya dan beragam. Nurcholish Madjid, seorang aktivis Pluralisme, mencatat bahwa terdapat empat ratus kelompok etnis dan bahasa yang berada di bawah naungan Negara Kesatuan Republik Indonesia (NKRI) (Hidayat, 2011). Di samping itu, variasi keragaman yang ada di Indonesia pun terlihat pada aspek

* Corresponding author

Received: September 01, 2019; Revised: October 19, 2019; Accepted: December 26, 2019 
lain, yaitu pada aspek agama dan kepercayaan-kepercayaan lokal yang tersebar luas dari Sabang sampai Merauke. Relatif tidak sulit untuk menemukan kehadiran mereka di setiap penjuru Indonesia, karena kemunculannya pun telah memberikan nafas dan warna tersendiri bagi Indonesia, yang mana diamanatkan untuk menjadi bangsa yang plural dan majemuk.

Keberadaan kelompok minoritas khususnya primal religion adalah tanggung jawab pemerintah secara ekslusif melalui Kementerian Agama (KEMENAG RI). Akan tetapi keberadaanya menempati situasi dan kondisi yang kurang diuntungkan. Mereka dianggap, contohnya, sebagai kelompok yang hanya menganut kepercayaan warisan nenek moyang. Dengan demikian, anggapan yang muncul ke permukaan ialah konsepsi bahwa akan lebih baik kiranya apabila kelompok-kelompok minoritas tersebut diakomodir dan didorong untuk bergabung ke dalam agama resmi negara.

Dalam pelbagai laporan penelitian suku "terasing" (kelompok minoritas) terdahulu yang memfokuskan diri pada suku-suku pedalaman di Asia Tenggara, salah satu suku terasing yang ada di Indonesia yaitu suku Baduy yang hidup di Banten menarik perhatian para ilmuwan baik lokal maupun internasional. Hal tersebut disebabkan karena komunitas itu tetap menjalani kehidupannya dengan sederhana dan alamiah di wilayahnya yang jauh dari sentuhan-sentuhan modernitas. Di antara faktor penyebab bertahannya masyarakat Baduy ditimbulkan dan diusung oleh kuatnya mereka dalam memegang tradisi adat dan kepercayaan yang "diwariskan" oleh para karuhun (leluhur) atau nenek moyangnya.

Ketaatan pada aturan adat dan keyakinan pada kepercayaan adalah salah satu faktor kunci integrasi masyarakat Baduy(Jacobs, 2012). Hal tersebut mengindikasikan bahwa apa yang dilakukan oleh masyarakat Baduy hingga hari ini kiranya sejalan dengan kesimpulan yang diungkapkan oleh Emile Durkheim, sosiolog dari Perancis, yang memberikan gambaran tentang fungsi agama (kepercayaan) dalam sebuah masyarakat sebagai sesuatu yang bersifat sosial.

Di sisi lain, kecenderungan para pengkaji agama, khususnya pada tataran ekspresi keberagamaannya, baik itu fokusnya pada agama-agama dunia maupun pada agama-agama lokal atau suku pedalaman, lebih menitikberatkan perhatiannya pada apa yang dilakukan oleh satu kelompok jenis kelamin saja, yakni jenis kelamin laki-laki. Misalnya, apa yang dilakukan dan dimanifestasikan oleh laki- laki biasanya dipandang lebih menarik, unik, dan berharga dibandingkan dengan hal-hal yang dilakukan oleh jenis kelamin yang lain yakni perempuan; sehingga selanjutnya konsepsi masyarakat dan agama akan digambarkan, diinterpretasikan, dan diuraikan seolah-olah hanya diciptakan, dimiliki, dan diwakili oleh laki-laki saja (Raden Cecep Eka Permana, 2011).

Rita M. Gross menyatakan bahwa sangat jarang ditemukan tentang informasi yang benar-benar dipikirkan, dirasakan, dan dilakukan oleh perempuan. Berbagai pandangan laki-laki atau stereoptip kultural tertentu tentang perempuan, tambah Gross, memanglah berguna, akan tetapi pandangan- pandangan tersebut tentu bukanlah sebuah informasi yang lengkap, utuh, dan menyeluruh tentang gambaran dari perempuan, dan bahkan mungkin bukanlah sebuah informasi yang mewakili kenyataan sebenarnya (Bruinessen, 1992).

Ketika berkunjung ke wilayah suku Baduy, terdapat beberapa cara yang dilakukan oleh kokolot (generasi awal) untuk berkomunikasi dengan generasi barunya. Salah satu caranya yaitu melalui komunikasi lisan. Media itu merupakan cara yang paling memungkinkan karena selain sudah dilakukan sejak lama secara turun-temurun oleh nenek moyang, bentuk komunikasi secara lisan juga diorientasikan untuk menjaga keutuhan masyarakat dengan tetap menjalin komunikasi secara erat melalui interaksi langsung antar penyampai waris dan pengemban waris (Burhani, 2012). 
Di antara bentuk komunikasi, seperti pelestarian tradisi yang diwariskan oleh para karuhun suku Baduy yang masih dipegang teguh dan mengandung nilai-nilai kesakralan, adalah melalui ritual akbar Seba (Hakiki, 2013). Tradisi itu, yang biasa dilakukan setiap tahun, merupakan prosesi tahap akhir atau puncak dari rangkaian tradisi yang harus dilakukan sebelumnya, seperti kawalu dan kalaksa. Tradisi sakral dari rangkaian ritual besar itu pun hanya dilakukan oleh orang-orang Baduy, baik generasi muda maupun generasi yang sudah lanjut dari suku Baduy. Ritual tersebut akan dilaksanakan setelah hasil olahan alam yang didapatkan (panen) selesai dikumpulkan.

Berkaitan dengan prosesi dari tradisi Seba di atas, terdapat hal yang sangat menarik dan khusus dari tahapan menjalani ritual Seba. Hal itu adalah aktor dari aktivitas dalam pembuatan laksa (ngalaksa) adalah para perempuan Baduy terpilih. Mereka berperan dominan dalam melakukan tahapan itu. Acuan utama atas pemilihan para perempuan itu didasarkan pada perilaku mereka sehari-hari. Di dalam mengikuti prosesnya, perempuan-perempuan yang telah terpilih itu dianjurkan untuk menjalani "puasa" selama pembuatan laksa berlangsung.

Terdapatnya peran perempuan di dalam menjalankan dan membantu proses ritual suci di atas, ternyata juga terlihat di dalam partisipasi saling mendukung dan membantu pada aktivitas sehari-hari. Contohnya yaitu ketika perempuan dan laki-laki Baduy pulang ke rumah masing-masing dari ngahuma pada waktu sore hari; pekerjaan-pekerjaan seperti memasak, mencuci, dan mengurus anak, yang umumnya dilakukan oleh perempuan, kerapkali dilakukan dan diambil alih pekerjaan itu oleh laki-laki Baduy. Hal itu terjadi juga pada kegiatan-kegiatan lain di luar rumah, seperti mencari kayu bakar, yang biasanya dilakukan oleh laki-laki, juga kerapkali dilaksanakan oleh perempuan Baduy. Menjalani aktivitas di dalam kehidupan sehari-hari oleh laki-laki dan perempuan Baduy adalah saling membantu dan mendukung satu sama lainnya.

Kegiatan lain yang dilakukan secara bersama-sama pun terlihat ketika lokasi untuk berladang (huma) sudah ditentukan. Seluruh anggota masyarakat, baik laki-laki maupun perempuan Baduy, mulai mengolahnya secara bersama-sama. Sebelum pengolahan lahan huma dimulai, biasanya terlebih dahulu diadakan acara ritual adat. Faktor utama dari diselenggarakannya acara itu diorientasikan untuk pencapaian hasil panen yang didapatkan nanti kiranya sesuai dengan apa yang diharapkan.

Berdasarkan pada temuan-temuan lapangan di atas, uraian-uraian tentang peranan masing- masing jenis kelamin dan pola saling mendukung adalah lebih baik daripada melihatnya sebagai sebuah bentuk perbandingan status dan nilai. Kebiasaan linguistik tentang laki-laki yang memiliki peran dominan dan perempuan sebagai yang pinggiran adalah ungkapan-ungkapan proyektif, dan umumnya mengandung nilainilai kultural tertentu yang bersifat relatif dan cenderung memaksakan diri pada sebuah masyarakat, yang mana pada sisi nilai-nilai budaya, umpamanya, jelas berlainan dan berbeda.

Oleh karena itu, dapat diambil tesis awal bahwa partisipasi yang diberikan oleh laki-laki dan perempuan Baduy dalam tradisi Sunda Wiwitan memiliki tempatnya masing-masing, dan pada kasus tertentu bisa saling mendukung dan bekerjasama satu sama lain secara sukarela, serta yang paling penting dari semua partisipasi dan kontribusi yang diberikan itu, didasari pada penghayatan secara total dan maksimal di dalam menjalankan segala ritual yang diwariskan oleh nenek moyangnya dalam kerangka keyakinan atas kepercayaan pada Sunda Wiwitan.

\section{METODE PENELITIAN}

Keberhasilan dari sebuah penelitian ditentukan oleh seperangkat cara yang diterapkan secara tepat, akurat, dan disusun secara sistematis. Hal itu juga difungsikan dan digunakan sebagai "pisau" 
analisis bagi keberadaan dari sebuah penelitian. Tindakan itu biasa disebut metode, yang dalam arti kata yang sesungguhnya, methodos, cara atau jalan (Koentjaraningrat, 1982).

Oleh karenanya, untuk memahami fenomena agama secara integral, Mukti Ali memberikan tiga metode yang diperlukan dalam memenuhi kebutuhan tersebut (Cresswell John W, 2014). Kelengkapan yang pertama sifatnya intelektual. Tujuannya ialah memahami agama atau fenomena agama secara menyeluruh, informasi yang penuh perlu dimiliki. Tidak ada harapan untuk memahami agama tanpa adanya informasi itu. Berkenaan dengan persyaratan tersebut, salah satu ialah aspek bahasa. Memiliki kemampuan bahasa adalah kunci dalam hal mempelajari suatu agama.

Kedua, usaha yang baik dalam memahami agama yang berbeda ialah dengan memerlukan kondisi emosional yang cukup. Usaha itu terwujud misalnya dengan pengalaman bergaul. Tindakan itu akan menolong peneliti memahami kajiannya secara optimal. Ketiga, kelengkapan itu adalah kemauan. Itu diperlukan bagi orang yang ingin mengerti agama orang lain. Kemauan tersebut ditujukan dan diorientasikan ke arah konstruktif. Keacuhan dan kecintaan yang tidak terkontrol, dan tidak adanya arah merupakan lawan dari kemauan yang menjadikan sebuah penelitian tentang pemahaman agama orang lain itu berhasil.

Kekeliruan dalam menggunakan metode penelitian, misalnya, akan berdampak pada proses dan hasil dari sebuah penelitian secara tidak memadai, dan bisa jadi kemungkinan selanjutnya, akan didapatkan sebuah kesimpulan akhir yang kurang tepat. Maka dari itu, di dalam penelitian ini, untuk mencapai hasil penelitian yang baik dan untuk menjawab permasalahan yang ada, serta mencapai tujuan dan maksud penelitian, akan diambil dan diterapkan seperangkat metode yang sistematis; dan untuk itu, penelitian ini menggunakan beberapa prosedur penelitian untuk mempermudah langkah di dalam melakukan penelitian (Sugiyono, 2013).

Di dalam penelitian terdahulu, seperti pada penelitian Saleh Danasasmita, Masyarakat Kanekes Keturunan Penghuni Sebuah Mandala (1983), Robert Wessing, The Position of Baduj in the larger West Javanese Society (1977), dan penelitian etnografi yang paling akhir, contohnya, Juditira K. Garna, Orang Baduy (1987), komunitas Baduy dimasukkan ke dalam cakupan pemerintahan Provinsi Jawa Barat. Baru dimulai pada awal tahun 2000, komunitas yang tinggal di sekitar Gunung Kendeng itu, hingga saat ini, berada di bawah naungan pemerintahan Kabupaten Lebak, Provinsi Banten.

Di dalam komunitas Baduy, terdapat banyak sekali kampung yang masuk ke dalam wilayah Desa Kanekes, namun tidak semua kampung yang ada di Kanekes dimasukkan ke dalam peneltian ini. Tempat atau lokasi yang akan dijadikan sebagai objek penelitian ini ialah kampung Baduy Dalam (Cibeo) dan kampung Baduy Luar(Kaduketug); kedua kampung tersebut termasuk wilayah Desa Kanekes, Kecamatan Leuwidamar, Kabupaten Lebak, Provinsi Banten.

Keputusan untuk memilih kampung-kampung itu adalah karena alasan teknis, yaitu akses yang mudah untuk ditemui oleh para wisatawan lokal dan mancanegara ketika berniat berkunjung ke daerah Baduy. Kampung yang biasa atau umum dilalui oleh komunitas non-Baduy dimulai dari kampung Kaduketug, dan kampung yang diperuntukkan bagi para pengunjung di kampung Baduy Dalam umumnya adalah Cibeo, di mana kampung ini sengaja ditempatkan sebagai kampung untuk para pengunjung mendapatkan keterangan atau informasi tentang Baduy.

\section{HASIL DAN PEMBAHASAN}

Tujuan dari disampaikannya contoh-contoh upacara keagamaan di bawah ini adalah memberikan pernyataan bahwa upacara keagamaan yang diselenggarakan oleh suku Baduy atas Sunda Wiwitan-nya memiliki gambaran atau status yang seimbang antar laki-laki dan perempuan. Hal demikian dilihat 
berdasarkan pengamatan lapangan dari rangkaian prosesi upacara keagamaan yang tidak mengandung perbedaan yang signifikan; dengan istilah lain, tidak ada keistimewaan yang berarti dari masing-masing jenis kelamin, sebagaimana di tempat lain di Indonesia, menurut hukum dan kepercayaan suku Baduy; status dan perannya adalah sangat penting dilihat dari kontribusinya masing-masing kepada kepercayaan Baduy, Sunda Wiwitan

Untuk uraian perihal upacara keagamaan yang pertama yang dilaksanakan oleh suku Baduy dan memiliki efek psikologis, peneliti akan memberikan dua upacara keagamaan yakni bentuk ritual yang memiliki makna dimulainya pengakuan oleh sebuah komunitas dan ritual keagamaan yang diasumsikan sebagai kondisi transisi dari pencapaian keagamaan (Piliang, 2010).

Kedua bentuk ritual di atas peneliti kontekstualisasikan menurut hukum adat Baduy atas anggota kelompoknya, baik konteks pengakuan melalui perayaan upacara keagamaan khitanan, untuk anggota suku Baduy yang berjenis kelamin laki-laki dan peperan untuk anggota suku yang berjenis kelamin perempuan, maupun konteks penyelenggaraan ritual pada saat perempuan melahirkan seorang anak sebagai peristiwa yang sangat penting. Akan tetapi, upacara keagamaan yang peneliti sudah sebutkan sebelumnya yaitu ketika perempuan-perempuan Baduy mendapatkan menstruasi, yang diterjemahkan sebagai titik perkembangan psikologis dan perubahan biologis, umumnya terjadi pada usia 12 tahun atau sedikit lebih lambat, tidak diselenggarakannya sebuah pesta ritual oleh masyarakat Baduy; situasi itu juga tidak dianggap sebagai sebuah kondisi yang memalukan atau tabu (Sujana, 2012).

Bentuk kemiripan dan perbandingan upacara keagamaan, yang diselenggarakan oleh orang-orang Baduy Dalam dan Baduy Luar dalam bentuk pelaksanaan ritual khitanan dan kelahiran di atas, tidak bertujuan menyamakan ritual-ritual itu secara mendasar dan radikal. Kualitas dan makna dari penghayatan pelaksanaan upacara keagamaan dalam tradisi Baduy adalah memberikan segala potensi yang dimiliki dan mentaati aturanaturan hukum adat Baduy. Di samping itu pula, peneliti hanya mencoba menyampaikan bahwa upacaraupacara keagamaan dalam tradisi Baduy yang memiliki efek psikologis merupakan pernyataan dalam kalimat "upacara khitanan yang ditangani oleh Bengkong adalah "seperti" yang dilakukan perempuan-perempuan (Paraji) ketika bayi dilahirkan

Sebuah penelitian yang menyajikan sebuah pengamatan atas ritual-ritual yang dilakukan oleh perempuan dan laki-laki secara terpisah, seperti Bengkong yang mengurus khitanan dan Paraji yang berperan menolong dalam urusan melahirkan anak, pada akhirnya akan menyajikan sebuah kesimpulan yang tidak utuh. Apabila hal tersebut dalam realitasnya sulit untuk dihindari, maka sikap yang umumnya diperlihatkan adalah memperbandingankan dan menitik beratkan pada jenis kelamin tertentu atas peran, status, dan makna upacara yang dijalani. Oleh karena itu, mengaitkan sebuah bentuk kerjasama dalam menjalani upacara keagamaan merupakan penekanan yang juga penting untuk diketahui. Situasi dan kondisi saling memberikan dan berkontribusi dalam kepercayaannya adalah dasar yang terlihat di dalam masyarakat Baduy, baik di komunitas Baduy Luar dan Baduy Dalam.

Dua bentuk saling memberikan peran atas kepercayaan Sunda Wiwitan peneliti klasifikasikan dan sebut sebagai bentuk ritual yang dilihat menurut keyakinan (teologis), seperti upacara kematian; dan ritual yang menitik beratkan kebersamaan dalam menjalani ritual yang sama, yang mana tujuan atas penyelenggaraan ritual tersebut adalah sama. Peneliti sebut yang terakhir itu dengan ritual yang mengandung signifikansi sosiologis.

Dengan mencermati uraian singkat dari dua praktek upacara keagamaan yang dilakukan secara bersama-sama di atas, peneliti coba tarik beberapa garis besar yang melatarbelakangi proses dan kontribusi laki-laki dan perempuan Baduy. 
Pertama, pelaksanaan upacara keagamaan, yang perempuan dan laki-laki Baduy lakukan secara bersama-sama melalui peran-peran yang sudah ambil alih dan berbeda konteksnya, menjelaskan bahwa perempuan yang menjalani proses laksa dan membantu keluarga yang sedang mengalami musibah kematian adalah bentuk ungkapan rasa empati dan saling melengkapi ritual yang ada.

Kedua, upacara-upacara keagamaan yang diselenggarakan oleh orang-orang Baduy kiranya menerangkan bahwa praktek-praktek yang dilakukan adalah bagian-bagian dari keseluruhan ritual. Artinya apa yang menjadi bagian dari perempuan secara mandiri adalah penting bagi tujuan laki-laki Baduy, begitupun sebaliknya, apa yang menjadi tugas laki-laki juga adalah istimewa bagi keinginan perempuan Baduy. Tuntasnya rangkaian-rangkaian pelaksanaan upacara yang dilakukan oleh masing- masing jenis kelamin akan menjamin keberhasilan ritual-ritual yang diselenggarakan secara keseluruhan. Ketiga, bentuk tindakan yang dilakukan oleh perempuan dan laki-laki Baduy secara bersama-sama memiliki arti bahwa mereka adalah mitra sejajar yang masing-masing dapat diasumsikan menempati posisi yang penting di dalam kehidupan agamanya.

Keempat, manifestasi-manifestasi yang perempuan Baduy lakukan di dalam konteks menjalani upacara keagamaan yang berbeda mengandung pengertian bahwa partisipasi mereka tidak kurang penting dibanding partisipasi laki-laki Baduy. Istilah lain yang lebih pantas kiranya adalah partisipasi yang dilakukan oleh perempuan Baduy kurang spektakuler di ranah publik.

\section{SIMPULAN}

Tantangan tradisi-tradisi suku, yang seringkali sulit diinterpretasikan karena literatur tentang tradisitradisi suku pada umumnya sangat androsentris, mulai terbuka. Pada awalanya kultur masyarakat tertentu cenderung menganggap bahwa partisipasi perempuan dianggap sebagai nomor dua, sedangkan partisipasi lakilaki mewakili gambaran yang ideal dan sentral. Sejarah pemahaman itu disebabkan oleh kata kodrat. Kata itu adalah keyword (kata kunci) bagi berlakunya hubungan gender (jender) di tengah- tengah masyarakat (Nurmila, 2014).

Proses sosialisasi kata kodrat menjadi kata kunci didukung oleh anggapan laki-laki memiliki fisik yang mampu mengantisipasi kekuatan alam daripada yang lain (perempuan). Penerjemahan akhir episode kata kunci itu ialah bahwa kemampuan laki-laki yang dominan, independent (merdeka), dan superior, sedangkan lawan jenisnya (perempuan) dipersepsikan sebagai marjinal, dependent (tergantung), dan inferior.

Terdapatnya fenomena partisipasi yang diberikan oleh perempuan dan laki-laki Baduy kepada kepercayaan Sunda Wiwitan merupakan realitas yang menekankan kebersamaan antara laki-laki dan perempuan sebagai mitra. Kenyataan tersebut menekankan bahwa manifestasi-manifestasi dari masingmasing jenis kelamin adalah sama-sama menempati posisi yang sangat penting dalam konteks kepercayaan mereka; dan paparan itu juga menyajikan sebuah koreksi ulang atas kebiasaan linguistik perihal pemahaman tentang peranan yang diberikan oleh perempuan sebagai pinggiran dan laki-laki sebagai dominan.

Upacara-upacara keagamaan yang dilaksanakan oleh orang-orang Baduy menerangkan bahwa praktekpraktek yang dilakukan adalah bagian-bagian dari keseluruhan ritual. Artinya apa yang menjadi bagian dari perempuan secara mandiri adalah penting bagi tujuan laki-laki Baduy, begitupun sebaliknya, apa yang menjadi tugas laki-laki juga adalah istimewa bagi keinginan perempuan Baduy. Tuntasnya rangkaian-rangkaian pelaksanaan upacara keagamaan yang dilakukan adalah komitmennya dalam kepercayaan Sunda Wiwitan. 


\section{DAFTAR PUSTAKA}

Bruinessen, M. Van. (1992). Gerakan Sempalan di kalangan umat Islam Indonesia: Latar Belakang Sosial Budaya, Ulumul Qur'an. Jurnal IImu Dan Kebudayaan, 3(1).

Burhani, A. N. (2012). Tiga Problem Dasar dalam Perlindungan Agama-Agama Minoritas di Indonesia. Jurnal Maarif Institute, 7(1).

Cresswell John W. (2014). Research Design; Pendekatan Kualitatif, Kuantitatif, dan Mixed. Yogyakarta: Pustaka Pelajar.

Hakiki, M. (2013). Makna Tradisi Seba Orang Baduy. Bandung: UIN Sunan Gunung Djati. Hidayat,

K. (2011). Memahami Bahasa Agama: Sebuah Kajian Hermeneutik. Bandung: Mizan.

Jacobs, J. (2012). Orang Baduy dari Banten, terj. Judistira K. Garna dan Salam Hardjadilaga. Bandung: Primaco Akademika \& Judistira Garna Foundation.

Koentjaraningrat. (1982). Masalah-Masalah Pembangunan. Jakarta: Bunga Rampai Antropologi Terapan. Jakarta: LP3ES.

Nurmila, N. (2014). Pembagian Waris Perspektif Keadilan Gender, Diktat Perkuliahan Pendidikan Gender. Bandung: UIN Sunan Gunung Djati.

Piliang, Y. A. (2010). Semiotika dan Hipersemiotika: Kode, Gaya, dan Matinya Makna. Bandung: Matahari.

Raden Cecep Eka Permana, D. (2011). Kearifan Lokal Tentang Mitigasi Bencana pada Masyarakat Baduy. Jurnal Makara, Sosial Humaniora, 15(1).

Sugiyono. (2013). Metode Penelitian Pendidikan Pendekatan Kauntitatif, kualitatif dan R\&D. Bandung: Alfabeta.

Sujana, A. M. (2012). Perkembangan Masyarakat Muslim pada Suku Baduy Dangka Kampung Kompol (1984-2012). Bandung: UIN Sunan Gunung Djati. 